\title{
SHERMAN'S OPERATOR INEQUALITY
}

\section{SlaViCA IVELIĆ BRADANOVIĆ, JADRANKA MićIĆ AND JOSIP PEČARIĆ}

\begin{abstract}
In this paper we deal with Sherman's inequality and its complementary inequalities for operator convex functions, whose arguments are the bounded self-adjoint operators from $C^{*}$-algebra on a Hilbert space and positive linear mappings between $C^{*}$-algebras. We introduce the so called Sherman's operator and study its properties. Applying an extended idea of convexity to operator functions of several variables, we obtain multidimensional Sherman's operator inequality. We define multidimensional Sherman's operator and study its properties. At the end, we observe applications to some operator inequalities related to connections, solidarities, and multidimensional weighted geometric mean.
\end{abstract}

Mathematics subject classification (2020): 47A63, 47A64.

Keywords and phrases: Operator convex function, positive linear mapping, Sherman's inequality, complementary to Sherman's operator inequality, multidimensional Sherman's operator inequality, Sherman's operator, multidimensional weighted geometric mean.

\section{REFERENCES}

[1] M. Adil Khan, S. IVElić BRAdAnOviĆ And J. PeČARIĆ, Generalizations of Sherman's inequality by Hermite's interpolating polynomial, Math. Inequal. Appl. 19 (4) (2016), 1181-1192.

[2] M. Adil Khan, S. Ivelić Bradanović and J. PeČarić, On Sherman's type inequalities for $n$-convex function with applications, Konuralp J. Math. 4 (2) (2016), 255-270.

[3] R. P. Agarwal, S. IVelić BRadanović and J. PeČarić, Generalizations of Sherman's inequality by Lidstone's interpolating polynomial, J. Inequal. Appl. 2016:6 (2016), pp. 18.

[4] S. S. Dragomir, J. E. PeČArić And L. E. Persson, Properties of some functionals related to Jensen's inequality, Acta Math. Hungar. 70 (1-2) (1996), 129-143.

[5] J. FujiI, M. Fujit, M. NAKAmura, J. PeČArić, AND Y. SEO, A reverse inequality for the weighted geometric mean due to Lawson-Lim, Linear Algebra Appl. 427 (2007), 272-284.

[6] J. J. Fujil, M. Fujil And Yuki Seo, An extension of the Kubo-Ando theory: Solidarities, Math. Japonica 35, 2 (1990), 387-396.

[7] T. FujiI, J. Mićić Hot, J. PeČArić And Y. Seo, Recent Developments of Mond-Pečarić Method in Operator Inequalities, Monographs in Inequalities 4, Element, Zagreb (2012).

[8] S. Furuichi, K. Yanagi And K. Kuriyama, A note on operator inequalities of Tsallis relative operator entropy, Linear Algebra Appl. 407 (2005), 19-31.

[9] T. Furuta, J. Mićić Hot, J. PeČARIĆ And Y. SEO, Mond-Pečarić Method in Operator Inequalities, Monographs in Inequalities 1, Element, Zagreb (2005).

[10] G. H. Hardy, J. E. Littlewood and G. Pólya, Inequalities, Cambridge Univ. Press, 2nd ed., Cambridge (1952).

[11] S. IVElić BRAdANOvić, N. LATIF AND J. PeČARIĆ, On an upper bound for Sherman's inequality, J. Inequal. Appl. 2016:165 (2016), pp. 17.

[12] S. IVelić BRAdanović, N. LATIF, Đ. PeČARIĆ AND J. PeČArić, Sherman's and related inequalities with applications in information theory, J. Inequal. Appl. 2018:98 (2018), pp. 21.

[13] S. IVELIĆ BRADANOVIĆ AND J. PEČARIĆ, Extensions and improvements of Sherman's and related inequalities for $n$-convex functions, Open Math. 15 (1) (2017), 936-947.

[14] S. IVelić Bradanović And J. PeČARIĆ, Generalizations of Sherman's inequality, Per. Math. Hung. 74 (2) (2017), 197-219. 
[15] M. Khosravi, J. S. Aujla, S. S. Dragomir and M. S. Moslehian, Refinements of Choi-DavisJensen's inequality, Bull. Math. Anal. Appl. 3 (2) (2011), 127-133.

[16] P. A. Kluza And M. Niezgoda, On Csiszár and Tsallis type $f$-divergences induced by superquadratic and convex functions, Math. Inequal. Appl. 21 (2) (2018), 455-467.

[17] M. KRnić, N. LOVRIČEVIĆ AND J. PeČARIĆ, Jensen's Operator and Applications to Mean Inequalities for Operators in Hilbert Space, Bull. Malays. Math. Sci. Soc. 35 (1) (2012), 1-14.

[18] M. KRnić, N. LovričEviĆ AND J. PeČArić, Multidimensional Jensen's operator on a Hilbert space and applications, Linear Algebra Appl. 436 (7) (2012), 2583-2596.

[19] J. MićIĆ, Z. PAVIĆ AND J. PEČARIĆ, Some better bounds in converses of the Jensen operator inequality, Oper. Matrices 6 (3) (2012), 589-605.

[20] M. NieZgoda, Nonlinear Sherman-type inequalities, Adv. Nonlinear Anal. 9 (1) (2020), 168-175.

[21] M. NieZgoda, Remarks on Sherman like inequalities for $(\alpha, \beta)$-convex functions, Math. Ineqal. Appl. 17 (4) (2014), 1579-1590.

[22] M. Niezgoda, Remarks on convex functions and separable sequences, Discrete Math. 308 (2008), $1765-1773$.

[23] M. NieZgoda, Vector joint majorization and generalization of Csiszar-Korner's inequality for $f$ divergence, Discrete Appl. Math. 198 (2016), 195-205.

[24] J. E. Pečarić, F. Proschan and Y. L. Tong, Convex Functions, Partial Orderings, and Statistical Applications, Academic Press. Inc., San Diego (1992).

[25] S. Sherman, On a theorem of Hardy, Littlewood, Pólya and Blackwell, Proc. Natl. Acad. Sci. USA, 37 (1) (1951), 826-831. 